\title{
Local communities' knowledge of lignite surface mining - sources and level of satisfaction: examples from central Poland
}

\author{
Jarosław Badera \\ Department of Applied Geology, Faculty of Earth Sciences, University of Silesia, Będzińska Str. 60, 41-200 Sosnowiec, Poland \\ E-mail address: jaroslaw.badera@us.edu.pl
}

\begin{abstract}
Developing of large-scale lignite excavation can often generate socio-environmental conflicts between mining-energy companies and various stakeholders, such as local communities or ecological organizations. In this context indication of potential channels of communication with local communities' is needed to increase the level of their satisfaction with own knowledge and to optimize the social dialogue. The paper presents the results of a questionnaire survey conducted in selected communities of the Łódź voivodeship where surface mining exists at present (Kleszczów) or will be developed soon (Złoczew). They were realized with the Computer Assisted Telephone Interviewing on the representative groups of adults. The paper contains analysis of two selected closed-type questions: the first one concerned self-assessment of knowledge level of lignite mining, the second one - sources of information on mining activity. Previous media reports on mining activity in the examined areas were analysed, too. As it seems, various means of social communication should be used: television and radio are the major source of information for local communities, printing press and the Internet are important as well. A detailed set of communication channels and the content of individual messages should be carefully selected for specific target groups (depending on gender, age and education). It should be emphasized that a properly conducted public debate may prove to be one of the factors determining the success of mining-energy investments and sustainable development of some regions.
\end{abstract}

KEY WORDS: brown coal, public opinion, social communication

\section{Introduction}

Public opinion is one of the most important social notions, particularly crucial in democratic society. It is a vague term, but nonetheless, valued as very important (DOBEK-OSTROWSKA ET AL., 1999). The issue of public opinion may be viewed as the group of the approaches characteristic for the given community. It serves not only the opinionmaking role, but also the integrating, controlling, consulting and creating ones (MŁYNIEC, 1996). Thus, the opinion of a society is an important predicator of investment of various kind, mining excavation included.

This concept particularly concerns lignite (brown coal) open-pit excavation, which means the involvement of the big area of land and the necessity to relocate the whole groups of the studied communities. Such approach results in evoking negative feelings towards mining, as its influence on the environment is perceived in strongly negative light. All of the above can generate socio-environmental conflicts among various stakeholders, such as mining-energy companies, other entrepreneurs, ecological organizations, local governments or inhabitants. The media play an important role in such types of conflicts and usually the views of the local community are presented in a more favourable manner.

The specificity of the external (environmental, social, legal and other) conditions of lignite excavation is described by, among others, KASZTELEWICZ \& ZAJĄCZKOWSKI (2010), NAWORYTA (2009, 2011), NAWORYTA \& BADERA (2012) or UBERMAN \& NAWORYTA (2012). The role of the groups of stakeholders and the mechanisms of 
conflicts was presented in detail in a publication by BADERA (2010), where it was claimed that one does not observe any major differences between conflicts connected with various types of exploitation (both surface and underground mining).

For the success of mining investment it is necessary to acquire social acceptance. It can be achieved only through dialogue, based on an open, two-way communication. Such communication between stakeholders, planned and implemented in accordance with specific standards can prevent crisis situations (KoCOŃ, 2010). To implement an appropriate information policy it is necessary to clarify the current state of knowledge of a particular community and the selection of optimal communication channels.

The purpose of the following analysis was to obtain information about the degree of satisfaction of subjected communities from its knowledge of mining activity and the sources from which this knowledge is usually obtained. These data can be used by investors and individual stakeholders also in debates on other investments.

\section{Methodology}

This paper presents the results of research that was done in 2012. The study was conducted according to generally accepted methodology of sociological research (BABBIE, 2009, 2010; GRUSZCZYŃSKI, 2002). A major part of the research was a quantitative analysis of the inhabitants' opinions in the chosen areas concerning the social and environmental aspects of surface lignite excavation. Fundamental results of this research are published in the author's another paper (BADERA \& KOCOŃ, 2013).

The smallest units, i.e. communes, of administrative division of central Poland (the Łódź province) were the objects of the study: Kleszczów, where the Bełchatów mine and power plant have been functioning since the end of the 1970s, nowadays owned by Polska Grupa Energetyczna company (PGE); and Złoczew, where most of the big lignite deposit is located; PGE plans that the deposit will be developed within the next few years.

The public opinion research was made with the use of a standard questionnaire form according to generally accepted rules (GRUSZCZYŃSKI,2003). In total it contained several questions, two of which are subject of the following analysis. The first one concerned self-assessment of knowledge level of mining activity. It was a closed question with answers based on a 4-level scale. The second concerned sources of information on mining excavation and contained 9 possible answers, from which respondents were to choose maximally 3 (therefore, response distribution does not aggregate to $100 \%$ ).

In both communes the basic qualitative research was realized with the CATI - Computer Assisted Telephone Interviewing on the representative groups of adults. The phone interviews were supported by the CADAS computer program (Computer Assisted Data Acquisition System). The selection of respondents was performed via a multi-level, random-quota procedure. A total of 300 interviews were conducted in the Kleszczów commune and 302 interviews in the Złoczew commune. Respondents (quota) were chosen due to their sex and age (groups below the age of 25, between 26-45, between $46-65$ and over 66 ). A 2stage stratified random sampling was used in the groups described above.

Processing the results was based firstly on verifying the results of the conducted research and then on processing them in the SPSS v. 19 statistic program. The report from the questionnaire research presents a layout of answers depending on the sex and age of the respondents as well as on their education level. Furthermore, the layout of answers was examined as to whether the respondents were for or against lignite excavation in Poland; their participation in both examined populations was assessed on the basis of analysis of the other question (BADERA \& KOCOŃ, 2013).

The statistic significance of the difference between the frequency of the chosen answers or the average marking was tested based on the Student's $t$ test and on single-factor variation analysis together with the Tukey's test, taking as the significance level $\alpha=0.05$. When calculating the average, the answers "it's difficult to say", "I don't know" "I can't say" were omitted. The paper is focused, first of all, on presenting and interpreting those differences that proved to be statistically significant. A lack of statistic confirmation means that there were no major differences between the studied populations or that these differences exist but have not been conclusively proved.

There was also characterized the media image of both communes within the subject of the research and there was analysed (in the set time limits) the contents of media, using the EMIS base (Emerging Markets Information Service) as well as the content of internet media using popular engine: Google. The particular attention was focused on local media, independent from local governments (paper media, Internet communities active in given communes, individual towns or villages). Radio and TV auditions were not analysed. 


\section{Media image of subject areas}

Media may play extremely important role in deciding "for or against the mine". Researching the EMIS database during the second half of 2011 there were found nine articles concerning the communities of Kleszczów. In the set period there was no news concerning the lignite output, nor the Bełchatów power plant. Among the news connected in any way with the researched subject there may only be mentioned the article in the Głos Szczeciński newspaper from the $22^{\text {nd }}$ November 2011, which enumerates Kleszczów as one of the communities which are the best in the balanced development competition.

At the same time in the EMIS database there were five articles concerning the Złoczew commune, none of them concerning mining. It was different in case of branch newspapers. On the $1^{\text {st }}$ September 2011 in the Energia-Gigawat newspaper it was stated that the representatives of the National Coalition "Development Yes - Outputs No" demand withdrawing the plan of accepting the Concept of the Country Land Management Until 2030 from the agenda of the Council of Ministers in August. The Nowy Przemyst magazine on $1^{\text {st }}$ December 2011 in the article entitled Coal Looses its Power in Europe stated that Złoczew was one of the new lignite reserves which are within the range of interest of the PGE group.

Internet sources (websites, Web portals and forum) were tested for the period of 2010-2011 and the first quarter of 2012. The range of the research was limited to the first hundred answers Google engine provided, and the topic only to the issues connected with the coexistence of the mine and the local community.

In January 2010 in the Dziennik Łódzki newspaper there appeared the article entitled Creaked Wall Should be Claimed in the Mine in Betchatow, which was also copied in the Naszemiasto.pl. Web portal. The article informs only about the procedures connected with claiming the mining damage.

The article in the Web portal Eurogospodarka.pl (July 2010) concerns the issue more, describing the achievements of the communities of Kleszczów and underlying the understanding the commune inhabitants showed towards the mining project.

The next article concerning the cooperation between the local inhabitants and the mine was not published until May 2011 on the Web portal Naszemiasto.pl. Although the article reports the situation from the perspective of the inhabitants, it is held in the objective tone and informs about the compromise in solving the issue.
Internet media inform somewhat more about the planned investment in the Złoczew community. During the analysed period on the Web portal Naszemiasto.pl there appeared 8 reprints from the Dziennik Łódzki newspaper that were connected with the planned lignite excavation, and 1 article of their own, concerning the same topic. The majority of them appeared in 2010 and initially were devoted mostly to the competition between two companies, PGE and PAK Górnictwo when trying to obtain the mining concession. Nonetheless, almost all of the articles also contain some information about buying grounds, workplaces, meetings with the inhabitants, plans to start a mining school etc. In most of them the positive approach of the local inhabitants is noted.

In February 2011 in the weekly magazine called Siedem Dni, from Sieradz (paper and Internet version) there was published the interview with one of the PGE directors. Its title was: To make Złoczew be like Kleszczów - speaks for itself. The information about the plans of excavation of the lignite reserves in Złoczew was presented in many other Web portals, mainly of economic character (such as WNP.pl, Bankier.pl, Cire.pl and others). The interesting and relatively matter-offact discussion was conducted on the Wielun Discuss Forum (Wielun.biz) between December 2008 and January 2012.

Analysing the media operating on the level of communes and its particular cities (independent from the local authorities), there was located only one newspaper in the community of Kleszczów (connected with the nonprofit organization) and two portals and 1 Internet forum. The topic directly connected with the activities of the mining-energy sector is completely absent. In the Złoczew commune there is only one active Internet forum, whose participants also did not show any interest in the studied period.

Summing up, in case of the community of Kleszczów there was observed no major media interest in the topic of local community coexistence with the mining-energy sector. This fact, as well as the objectivity of some of the published information may be interpreted as the way of expressing general acceptance for the actions of PGE in this area, both from the local inhabitants and from the media themselves. On the other hand the topic of the planned mine in Złoczew, as a kind of the news, evoked relatively strong media attention, mainly regional and business ones. The majority of them present relatively objective information. In contrast to most of other mining investments (which concerns mainly lignite) media engagement on the social stakeholders' side (inhabitants, 
ecological organizations) was not observed - and that could enlarge or even create socioenvironmental conflict.

\section{Self-assessment of inhabitants' knowledge of mining activity}

The aim of conducted research was not a verification of the real knowledge level, but determining in what degree it is satisfying for

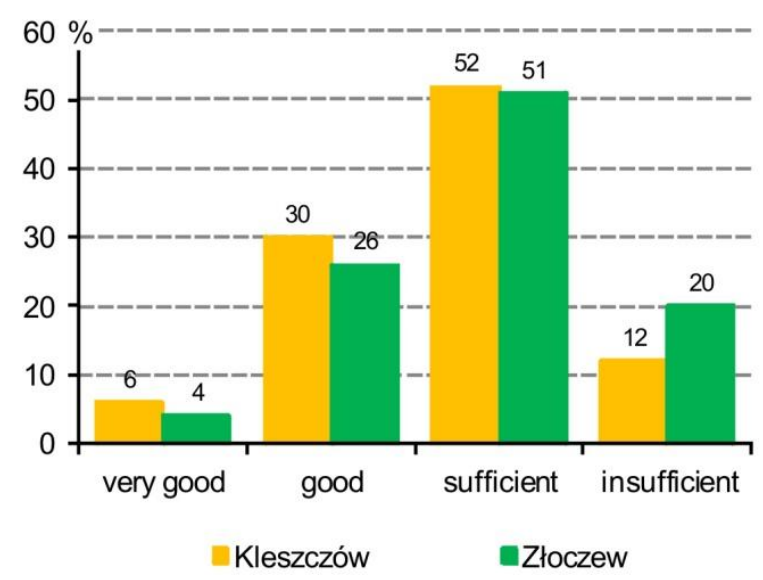

Fig. 1. How do you assess your knowledge level about brown coal mining, its economic role and its influence on the environment? The inhabitants of the Kleszczów community $(\mathrm{n}=300)$ and the Złoczew community $(\mathrm{n}=302)$ separately (Source: Telephone interviewing (CATI), January-February 2012)

Satisfaction from the obtained knowledge does not depend on the age or education level. However, women assess their knowledge level lower than men (especially women living in the Złoczew community, $30 \%$ of whose describe it as insufficient). Nonetheless, about half of the women seem satisfied and over $25 \%$ even pleased with it.

In the Kleszczów community people professionally connected with the mining-energy sector definitely higher assess their knowledge level, which seems logical. In the Złoczew community the inhabitants of the relocated villages assess their knowledge the highest. This observation was not confirmed statistically (due to the big difference in numbers in both pools), therefore it may be only ostensible. However, the study offers another explanation: information actions were addressed mostly to the inhabitants of the relocated villages which would prove them being correctly prepared and conducted. However, it is somewhat contradicted by the answer for the question concerning the information sources - the Złoczew community inhabitants (both relocated and the rest) assess as low (underestimate?) the meaning of the official information from the company and from the local government when compared to other the inhabitants of both communes and whether it may influence their attitude towards mining.

It was found that the Kleszczów community inhabitants assess their knowledge of lignite mining somewhat higher than the inhabitants if the Złoczew community. Nevertheless, in both cases the possessed knowledge level was generally satisfying for the inhabitants - over $50 \%$ assessed it as satisfactory, almost $40 \%$ as good and even very good (Fig. 1).

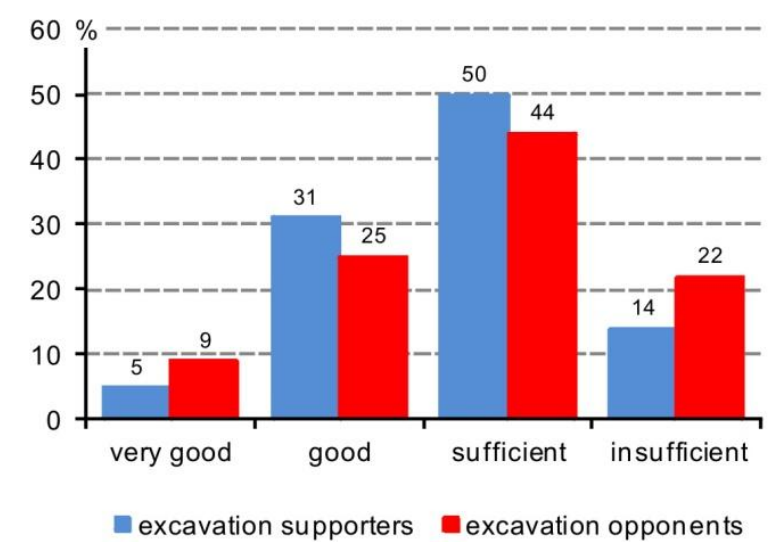

Fig. 2. How do you assess your knowledge level about brown coal mining, its economic role and its influence on the environment? The inhabitants of the Kleszczów community $(\mathrm{n}=300)$ and the Złoczew community $(\mathrm{n}=302)$ together (Source: Telephone interviewing (CATI), January-February 2012)

sources. Based on the results of research it can be concluded that the opponents of lignite output are characterized by the lower level of satisfaction from their knowledge of mining activity compared to the supporters (Fig. 2). Due to the small number of the former group it was not possible to prove this issue without a doubt in the statistic sense.

\section{Sources of inhabitants' knowledge of mining activity}

Determining the sources of the social knowledge and opinions may be important from the perspective of excavation companies. It is important that the question did not only concerned the information about lignite, but also resources in general and its major goal was to specify the best information channels, not just an actual state of knowledge concerning the particular investment. Generally, both communities inhabitants looked for the information concerning resources excavation from the same sources (Fig. 3). The only important difference is definitely higher level of basing on their own experiences among the Kleszczów community inhabitants. 


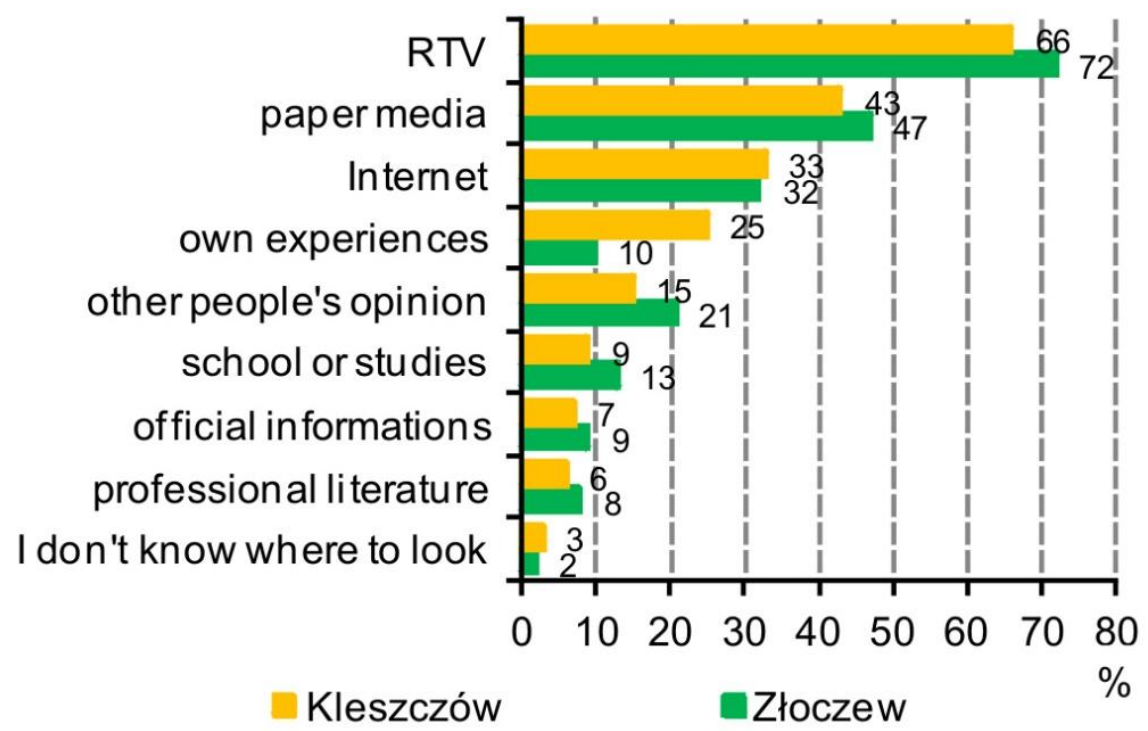

Fig. 3. What is your main source of information about resources excavation? Please indicate three from among the given ones. The inhabitants of the Kleszczów community $(n=300)$ and the Złoczew community $(n=302)$ separately

(Source: Telephone interviewing (CATI), January-February 2012)

The main source of knowledge is television and radio (RTV; in the question those types of sources were not divided, although probably the television is more significant). It presumably concerns not only mineral resources, but all the aspects of socioeconomic life. Paper media and the Internet are also of great importance. Own experiences (the Kleszczów community) and other people's opinions (the Złoczew community) seem to be the locally important source of information. The importance of other information sources is, in the respondents' opinion, rather small. However, they may not appreciate some of them enough, although in fact they carry the information that stays long in their memory. Such influence may probably have the information action led by PGE, especially the presence of information point in Złoczew and the meetings with the local inhabitants. It should also be noted that in case of both examined communes ecological organizations and other third sector organizations were not present as the information source. Merely small percentage of people do not know at all where to look for the information. Although nobody claimed they do not seek such information it should be supposed that the inhabitants are in some way rather passive receivers: they obtain the information watching TV or looking through the newspapers.

As far as the used information sources are concerned, there are visible differences between people of various ages (Fig. 4). The respondents up to 25 more often than the rest indicated the Internet. The importance of the Internet for this group is similar or even bigger than of the RTV. When the respondents are older there is the visible decreasing tendency in using the Internet: in the next age group (26-45) the Internet is used as willingly as paper media and in two oldest age groups RTV and paper media are dominant. Besides, the people aged up to 25 more often indicate school or studies as the information source than the people from other age groups. In the Kleszczów commune own experience is of more importance in case of the older age groups than in younger ones (the difference not confirmed statistically).

Women significantly more often than men indicated RTV, paper media and official information given by the local government or the mining company. Men, more often than women pointed to their own experiences. Nonetheless, RTV is the basic information source for both men and women (Fig. 5).

RTV (as a knowledge source) dominates regardless education level, although in case of people with higher education in the Kleszczów community Internet seems equally important. The dominance of RTV over other information sources (especially paper media) is visible particularly in case of people having elementary or lower secondary (junior high school) education. Other groups use more diversified information sources (Fig. 6). Own experiences play bigger role in the case of the Kleszczów community than in the Złoczew one. 


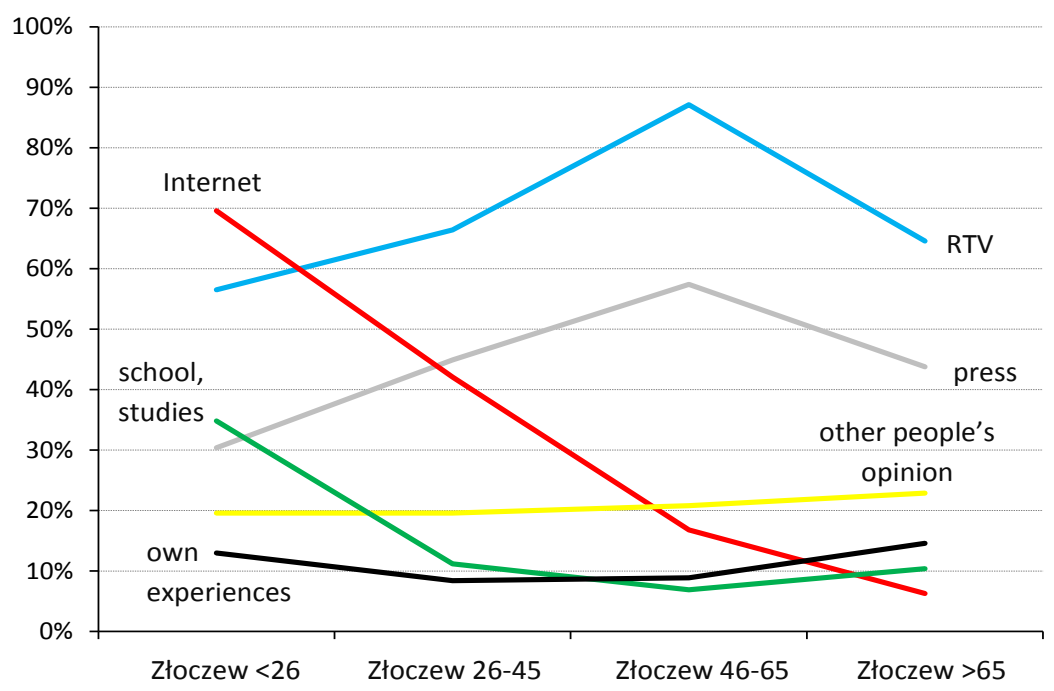

Fig. 4. What is your main source of information about resources excavation? Please indicate three from among the given ones. The inhabitants of the Złoczew community $(\mathrm{n}=302)$ divided by age groups (Source: Telephone interviewing (CATI), JanuaryFebruary 2012)

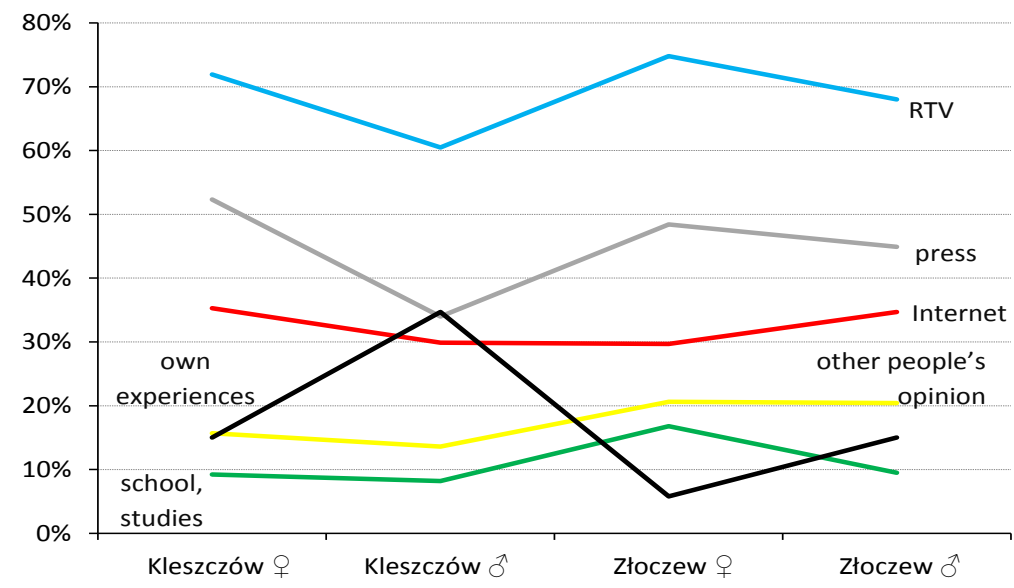

Fig. 5. What is your main source of information about resources excavation? Please indicate three from among the given ones. The inhabitants of the Kleszczów community $(n=300)$ and the Złoczew community $(n=302)$ separately, divided by gender (Source: Telephone interviewing (CATI), January-February 2012)

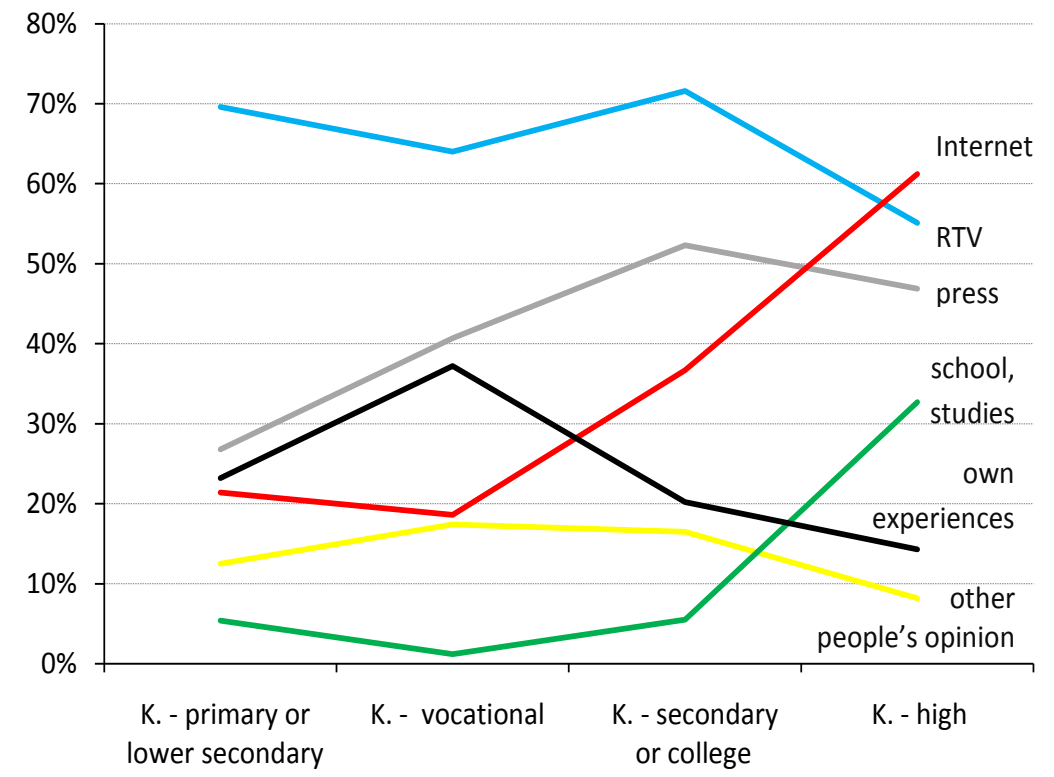

Fig. 6. What is your main source of information about resources excavation? Please indicate three from among the given ones. The inhabitants of the Kleszczów community $(\mathrm{n}=300)$ divided by education level (Source: Telephone interviewing (CATI), January-February 2012) 
The attitude towards lignite excavation in Poland is not different among local communities when taking into account various information sources. Both supporters and opponents of the mining were indicating the same sources of information with the similar frequency. It means that the attitude towards mining is not the result of using different information sources. Therefore to persuade the opponents of mining, all sources available may be used in a way that differs in their range and influence ability.

\section{Conclusions}

From the perspective of the mining companies, local authorities and other stakeholders of the mining industry, it is advisable to follow the information actions, especially due to the fact that the excavation opponents seem less satisfied with their knowledge of the subject.

These actions should be largely addressed to women, because a relatively big part of them assesses their knowledge of the subject as insufficient. At the same time it is a group significantly less inclined to accept the negative effects of mining activity (probably to relocation, too). Women also constitute the majority of persons unable to take a definite stand on this matter. Probably (the difference is statistically insignificant) older or poorly educated persons are less satisfied with their knowledge, as well as more indecisive in some issues.

For local communities the main source of knowledge is television and radio, paper media and the Internet are also of great importance. Various means of communication should be used to communicate with the communities, but a detailed communication scheme and contents ought to be precisely organized and adapted to specific target groups (depending on gender, age and education). The communication model should at the same time be of the dialogue type, which will enable potential changes in the decision model from the typically decisive for the more participating one. A properly conducted public debate may become one of the factors determining an investment success and sustainable development of some regions.

\section{Acknowledgments}

The article presents the results of research funded by PGE Górnictwo i Energetyka Konwencjonalna Spółka Akcyjna company (PGE GiEK SA) in Bełchatów on the basis of donation contract PD/229/2011 which was signed with the University of Silesia in Katowice. The author would like to thank all of the persons who directly took part in or acted as consultants during the research, especially Jerzy Cabała D.Sc. (University of Silesia), Artur Cieśliński (Inny Format company), employees of PGE GiEK SA (Department of Communication) and all of the inhabitants of the Kleszczów and Złoczew communes who answered the questions.

\section{References}

Babbie E.R. 2009. The basics of social research. Wadsworth/ Cengage Learning, Belmont.

Babbie E.R. 2010. The practice of social research. Wadsworth/ Cengage Learning, Belmont.

Badera J. 2010. Social conflicts on the environmental background related to development of mineral deposits in Poland. Gosp. Sur. Mineral., 26, 1: 105-125 (Abstract in English).

Badera J., Jaksoń, M. 2011. The role of mass-media in miningrelated social-environmental conflicts. Prace Nauk. Inst. Górn. Politech. Wrocławskiej, 132, Studia i Mat. 39, Górn. i geol. XV: 3-9 (English summary).

Badera J., Kocoń P. 2013. Local community opinions regarding the socio-environmental aspects of lignite surface mining: experiences from central Poland. Energy Policy (http://dx.doi.org/10.1016/j.enpol.2013.11.048i).

Dobek-Ostrowska B., Fras J., Ociepka B. 1999. Teoria i praktyka propagandy. Wyd. Uniw. Wrocł., Wrocław.

Gruszczyński L.A. 2002. Elementy metod i technik badań socjologicznych. Śląskie Wyd. Nauk., Tychy.

Gruszczyński L.A. 2003. Kwestionariusze w socjologii: budowa narzędzi do badań surveyowych. Wyd. Uniw. Śl., Katowice.

Kasztelewicz Z., Ptak M. 2009. Chosen problems of securing brown coal deposits in Poland for opencast mining activity. Polityka Energ., 12, 2/2: 263-276 (Abstract in English).

Kasztelewicz Z., Zajączkowski M. 2010. Impact of lignite mining on it surroundings. Polityka Energ., 13, 2: 227-243 (Abstract in English).

Kocoń P. 2010. Communication standards in local government as means of crisis protection. Zeszyty Nauk. WSOWL, 157, 3: 389-397 (English summary).

Młyniec E. 1996. Opinia publiczna. [in:] Jabłoński A.W., Sobkowiak L. (eds.) Studia z teorii polityki, vol. 1., Wyd. Uniw. Wrocł., Wrocław.

Naworyta W. 2009. The importance of environmental conditions for mining accessibility of lignite deposits in Poland. Polityka Energ., 12, 2/2: 423-434 (Abstract in English).

Naworyta W. 2011. Analysis of geological and mining conditions and external restrictions for lignite extraction from deposit Gubin. Polityka Energ., 14, 2: 291-304 (Abstract in English).

Naworyta W., Badera J. 2012. Analysis of social and economic conditions for planned development of Gubin lignite deposit. Polityka Energ., 15, 3: 107-117 (English summary).

Naworyta W., Chodak M., 2010. Analysis of environmental, social and cultural conditions of lignite extraction in Gubin region. Zesz. Nauk. Uniw. Zielonogórskiego, 137, Inżynieria Środowiska 17: 45-55 (English summary).

Sztumski J. 2010. Wstęp do metod i technik badań społecznych. Wyd. Śląsk, Katowice.

Uberman R. 2008: Property title and value of brown coal deposits. Polityka Energ., 13, 2: 449-457 (Abstract in English).

Uberman R., Naworyta W. 2012. Lignite exploitation under spatial and environmental restrictions - case study: Gubin lignite deposit. Polityka Energ., 15, 4: 29-41 (English summary). 